\title{
A call to silviculturists for a new field of science: The forestry of invasive alien species
}

\author{
by Tommaso Sitzia'
}

\begin{abstract}
A new field of forestry science is required to assume the responsibilities that a new European regulation will give to Member States. Are silviculturists ready to share and improve scientific knowledge on the management of invasive tree species alien to Europe?
\end{abstract}

Keywords: biodiversity conservation, biological invasion, alien tree species, land abandonment, black locust

\section{RÉSUMÉ}

Un nouveau domaine des sciences forestières doit être créé afin d’assumer les responsabilités qu’une nouvelle règlementation européenne octroiera à ses états membres. Est-ce que les sylviculteurs sont prêts à partager et à approfondir les connaissances scientifiques portant sur les espèces envahissantes arborescentes étrangères en Europe?

Mots clés : préservation de la biodiversité, invasion biologique, espèces envahissantes arborescentes, abandon des terres,

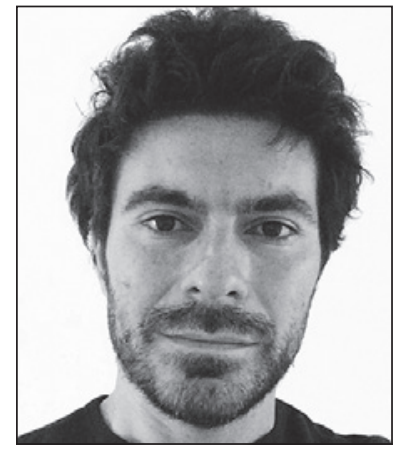

Tommaso Sitzia
In 1817 Heinrich Cotta published the first edition of a widely heralded book "Anweisung zum Waldbau" (Instruction or Course in Afforestation). In his book's preface, Cotta affirmed "This science [forestry] is only a child of necessity or need, and need is therefore its natural concomitant [...] We have now a forestry science because we have a dearth of wood" (Cotta 1817). Cotta, who defined himself as a "child of the forest", is a renowned pioneer of scientific forestry and founder of the oldest academy of forestry in Germany. Whatever his intellectual legacy is, we must acknowledge that, for 200 years, woodlands expanded throughout Europe. In the past two decades alone, the total forest growing stock has increased by 8.6 billion $\mathrm{m}^{3}$. In the same period, the area of forest in Europe has increased by 0.8 million ha per year (Forest Europe, UNECE and FAO 2011) as a result of socio-economical changes that are driving the progressive disappearance of non-forest, semi-natural land cover types (McDonald 2000) such as traditional pastures and meadows, which are part of alpine cultural landscapes, or their fragmentation into small isolated patches (Sitzia and Trentanovi 2011). To counter this trend, Habitats Directive (92/43/EEC), which is built around the Natura 2000 network of protected sites, aims to achieve "favourable conservation status" for a number of semi-natural habitats potentially threatened by forest expansion, over several biogeographically distinct regions (European Commission 2013). Of greatest concern is the invasion of these habitats by alien tree species. The list of the top 100 invasive alien species in Europe published by DAISIE (Delivering Alien Invasive Species In Europe), a project funded by the sixth framework programme of the European Commission (http:// www.europe-aliens.org/speciesTheWorst.do), includes black locust (Robinia pseudoacacia L.), black cherry (Prunus serotina Ehrh.), tree-of-heaven (Ailanthus altissima [Mill.] Swingle) and mimosa (Acacia dealbata Link). The first two species are native to North America, the other two species to China and Australia, respectively. The more local, the grimmer the situation looks. For example, in the area of Colli Euganei, a regional park and Natura 2000 site in Northern Italy, alien tree species dominate half of the forests (http://www.parcocollieuganei.com/index. php/piano-di-gestione-zps).

On 16 April 2014 the Parliament of the European Union adopted a first-reading position on the proposal for a longawaited (Hulme et al. 2009) regulation on the prevention and management of the introduction and spread of invasive alien species (Council of the European Union 2014). The definition of invasive alien species in this regulation fits many forest species like black locust, which has become extensively naturalized in Europe (Cierjacks et al. 2013). For instance, pure or mixed stands of this species now cover some 400000 ha in Hungary (Rédei et al. 2011), 200000 ha in France (Service de l'inventaire forestier et statistique 2012), 250000 ha in Romania (Enescu and Dănescu 2013) and 230000 ha in Italy (Tabacchi et al. 2007). This could be why black locust is one of the few species explicitly cited by the opinion adopted on 22 January 2014 by the European Economic and Social Committee (2014) as a case species which, although there is risk of further spread, "is still much appreciated: for stakes, sturdy wood for outdoor furniture, honey". For several years researchers have been warning of its effect on biodiversity of several organisms, such as lichens (Nascimbene and Marini 2010) and plants in rural (Sitzia et al.

\footnotetext{
${ }^{1}$ Università degli Studi di Padova - Dept. Land, Environment, Agriculture and Forestry, Viale dell'Università 16, I-35020 Legnaro (PD), Italy. E-mail: tommaso.sitzia@unipd.it
} 
2012), urban (Trentanovi et al. 2013) and forest environments (Petrášová et al. 2013).

Black locust and other forest species might be included among those to which chapter IV, "Management of Invasive Alien Species that are widely spread", is dedicated. According to Article 19 in this chapter, Member States will be obligated to "have in place effective management measures [...] so that their [invasive alien species] impacts on biodiversity, the related ecosystem services, and, where applicable, on human health or the economy are minimized". These management measures "shall consist of physical, chemical or biological actions aimed at the eradication, population control or containment of a population of an invasive alien species". Article 20 promotes "appropriate restoration measures to assist the recovery of an ecosystem that has been degraded, damaged, or destroyed by invasive alien species". This article explicitly refers back to Recital 26 of the preamble, which advocates proportionate restoration measures "to repair the damage caused and to enhance the conservation status of species and their habitats in accordance with Directives 92/43/EEC and 2009/147/EC". These two Directives form the cornerstone of Europe's nature conservation policy (http:// ec.europa.eu/environment/nature/legislation/habitatsdirective/ index_en.htm).

Recital 21 of the preamble advises Member States to "undertake research, monitoring and surveillance of such species and exchange best practices on the prevention and management of invasive alien species". Significantly, the explanatory statement chapter of the official report on the proposal by the European Parliament (Committee on the Environment, Public Health and Food Safety 2014) includes an assertion that invasive alien species "hamper forestry". A discussion paper by European Commission (http://ec.europa.eu/environment/ nature/invasivealien/docs/ias_discussion_paper.pdf) cites forestry three times. First, pointing to invasive alien species causing "major economic problems related to their prevention, control and eradication (e.g. [...] damages to forestry...)", then pointing to forestry as a pathway of their unintentionally introduction. Finally, this paper refers to forestry as one of the "potential measures to manage the issue". Definitely, here the management of forest species (i.e., forestry or, more specifically, silviculture) is regarded as an action that potentially favours alien invasive species, for example through coppicing alien tree species that are particularly competitive when resprouting (Radtke et al. 2013), or as a measure to control their influence on stand composition and structure by introducing silvicultural systems that account for the observed effects on biodiversity (Motta et al. 2009).

To date, the European Union's treaties make no provision for a common forest policy, because "National forest policies are formulated within a clearly defined framework of established ownership rights and with a long history of national and regional laws and regulations based on long-term planning" (http:// ec.europa.eu/environment/forests/home_en.htm). In other words, European silviculture is influenced by profound cultural and historical legacies, which are difficult to deal with at broad scales. It is for this reason that forest science is still not adequately recognized as a distinct science by the public and the scientific community, while other sciences are supported by public awareness. Similarly, there is an absence of a scientific approach to the forestry of invasive species alien to Europe, apart from rare scientific works that tend to focus on plantations (Rédei et al. 2011). However, forestry is a means of resolving conflicts among the attributes of alien species according to the principles of close-to-nature silviculture. The forestry of invasive alien species should focus on the effects of silvicultural treatments on: a) composition and structure of spontaneously developed and planted stands, b) invasion of adjacent native woodlands, c) invasion of adjacent semi-natural and natural non-wooded ecosystems, d) phenotypic and genetic differentiation between native and introduced populations, and e) provision of ecosystem services. As alien tree species are introduced they undergo rapid evolutionary change. Meanwhile, cultural, social and habitat conditions change rapidly and silviculturists do not only watch passively. Hence, interpretation of these changes should consider the cultural history of forestry. A paper by Hulme et al. (2009) published in the journal Science was titled "Will threat of biological invasions unite the European Union?" due to the need for coordinated action to face the socio-economic and cultural challenges that this regulation will pose to Member States. Still, for the regulation to work non-European countries should also be united. Silviculturists from North America, China and Australia should be called upon to share their experience in the management and control, in their native ranges, of the "worst" tree invasive species alien to Europe and collaborate on the collection of samples for phenotypic and genetic analysis. Silviculturists from other countries and continents, in a changing climate and land use scenario, should eventually be involved. Unfortunately, "The forester who practises much writes but little, and who writes much practises but little" as Cotta wrote in 1817, and this is "why forestry is still so backward".

Forests cover $42 \%$ of the area of Europe (http://ec.europa.eu/ environment/forests/home_en.htm). Yet, an impressive portion of this area is covered by invasive alien tree species. It is time to form and to disseminate solid scientific bases for forestry of INVASIVE ALIEN SPECIES, a new "child of necessity", and silviculturists have a role as active members of the Scientific Forum identified in Article 28 of this forthcoming regulation. The regulation is expected to be formally adopted by the Council and, according to Article 33, enter into force on 1 January 2015 (Council of the European Union 2014).

\section{References}

Cierjacks, A., I. Kowarik, J. Joshi, S. Hempel, M. Ristow, M. Lippe and E. Weber. 2013. Biological Flora of the British Isles: Robinia pseudoacacia. J. Ecol. 101(6): 1623-1640. doi: 10.1111/1365-2745.12162.

Committee on the Environment, Public Health and Food Safety. 2014. REPORT - Plenary sitting on the proposal for a regulation of the European Parliament and of the Council on the prevention and management of the introduction and spread of invasive alien species (COM(2013)0620 - C7-0264/2013 - 2013/0307(COD)) (RR\1018087EN.doc). European Parliament, Brussels. Available at http://www.europarl.europa.eu/sides/getDoc.do?type= REPORT\&reference=A7-2014-0088\&language $=$ EN\#title2 [Accessed 29 May 2014].

Cotta, H. 1817. Anweisung zum Waldbau. Zweite sehr vermehrte Auflage. Vorwort. Arnoldischen Buchhandlung, Dresden, pp. 3-8. [Translated from German by For. Quat. 1(1): 3-5] Available at https:// archive.org/details/forestryquarterl01newy [Accessed 4 May 2014].

Council of the European Union. 2014. Proposal for a Regulation of the European Parliament and of the Council on the prevention and management of the introduction and spread of invasive alien species - Outcome of the European Parliament's first reading (Strasbourg, 14 to 17 April 2014) Interinstitutional File: 2013/0307(COD). Council of European Union, Brussels. Available at http://register.consilium.europa.eu/doc/srv?l=EN\&f=ST\%209019\%202014\%20INIT [Accessed 5 May 2014]. 
Enescu, C.M. and A. Dănescu. 2013. Black locust (Robinia pseudoacacia L.) - an invasive neophyte in the conventional land reclamation flora in Romania. Bulletin of the Transilvania University of Braşov Series II 6(55) No. 2: 23-30. Available at http://rs.unitbv.ro/Bulletin/ Series\%20II/BULETIN\%20II/04_Enescu\%20and\%20Danescu.pdf [Accessed 5 May 2014].

European Commission. 2013. Interpretation Manual of European Union Habitats - EUR 28. European Commission, DG Environment, Brussels. Available at http://ec.europa.eu/environment/nature/legislation/habitatsdirective/docs/Int_Manual_EU28.pdf [Accessed 5 May 2014].

European Economic and Social Committee. 2014. Opinion of the European Economic and Social Committee on the Proposal for a regulation of the European Parliament and of the Council on the prevention and management of the introduction and spread of invasive alien species COM(2013) 620 final - 2013/0307(COD). European Economic and Social Committee, Brussels. Available at http://eescopinions.eesc. europa.eu/eescopiniondocument.aspx?language=en\&docnr $=6354 \& y e$ ar=2013 [Accessed 5 May 2014].

Forest Europe, UNECE and FAO. 2011. State of Europe's Forests 2011. Status and Trends in Sustainable Forest Management in Europe. Ministerial Conference on the Protection of Forests in Europe, Madrid. Available at http://www.foresteurope.org/documentos/State_of_Europes_Forests_2011_Report_Revised_November_2011.pdf [Accessed 4 May 2014].

Hulme, P.E., P. Pyšek, W. Nentwig and M. Vilà. 2009. Will threat of biological invasions unite the European Union? Science 324(5923): 40-41. doi: 10.1126/science.1171111.

McDonald, D., J.R. Crabtree, G. Wiesinger, T. Dax, N. Stamouc, P. Fleuryd, J. Gutierrez Lazpita and A. Gibon. 2000. Agricultural abandonment in mountain areas of Europe: Environmental consequences and policy response. J. Env. Manage. 59(1): 47-69. doi: 10.1006/jema.1999.0335.

Motta, R., P. Nola and R. Berretti. 2009. The rise and fall of the black locust (Robinia pseudoacacia L.) in the "Siro Negri" Forest Reserve (Lombardy, Italy): lessons learned and future uncertainties. Ann. For. Sci. 66(4): 1-10. doi: 10.1051/forest/2009012.
Nascimbene, J. and L. Marini. 2010. Oak forest exploitation and black-locust invasion caused severe shifts in epiphytic lichen communities in Northern Italy. Sci. Total Environ. 408(22): 5506-5512. doi: 10.1016/j.scitotenv.2010.07.056.

Petrášová, M., I. Jarolímek and J. Medvecká. 2013. Neophytes in Pannonian hardwood floodplain forests-History, present situation and trends. For. Ecol. Man. 308: 31-39. doi: 10.1016/j.foreco.2013.07.041.

Radtke, A., S. Ambraß, S. Zerbe, G. Tonon, V. Fontana and C. Ammer. 2013. Traditional coppice forest management drives the invasion of Ailanthus altissima and Robinia pseudoacacia into deciduous forests. For. Ecol. Man. 291: 308-317. doi: 10.1016/j.foreco.2012.11.022.

Rédei, K., I. Csiha, Z. Keserü, A.K. Végh and J. Györi. 2011. The Silviculture of Black Locust (Robinia pseudoacacia L.) in Hungary: a Review [online]. South-East Eur. For. 2(2): 101-107. doi: 10.15177/ seefor.11-11.

Service de l'inventaire forestier et statistique. 2012. Inventaire forestiere. Tableaux personnalises. Institut national de l'information géographique et forestière, Saint-Mandé Cedex, France. Available at http://inventaire-forestier.ign.fr/spip/spip.php?rubrique18 [Accessed 5 May 2014].

Sitzia, T. and G. Trentanovi. 2011. Maggengo meadow patches enclosed by forests in the Italian Alps: evidence of landscape legacy on plant diversity. Biodiv. Conserv. 20(5): 945-961. doi: 10.1007/ s10531-011-0006-3.

Sitzia, T., T. Campagnaro, M. Dainese and A. Cierjacks. 2012. Plant species diversity in alien black locust stands: A paired comparison with native stands across a north-Mediterranean range expansion. For. Ecol. Man. 285: 85-91. doi: 10.1016/j.foreco.2012.08.016.

Tabacchi, G., F. De Natale, L. Di Cosmo, A. Floris, C. Gagliano, P. Gasparini, L. Genchi, G. Scrinzi and V. Tosi. 2007. - Le stime di superficie 2005 - Prima parte. Inventario Nazionale delle Foreste e dei Serbatoi Forestali di Carbonio. MiPAF - Corpo Forestale dello Stato - Ispettorato Generale, CRA - ISAFA, Trento, Italy. Available at http:// www.infc.it [Accessed 5 May 2014].

Trentanovi, G., M. Lippe, T. Sitzia, U. Ziechmann, I. Kowarik and A. Cierjacks. 2013. Biotic homogenization at the community scale: disentangling the roles of urbanization and plant invasion. Divers. Distrib. 19(7): 738-748. doi: 10.1111/ddi.12028. 